\title{
Constitution and Molecular Species of Triacylglycerol in Meat and Giblet Lipids from Spent Laying Hen
}

\author{
Akihiro Hirata, Feng Chou Wang, Teiji Kimura and Yoshiyuki Ohtake \\ College of Agriculture and Veterinary Medicine, \\ Nihon University, Setagaya-ku, Tokyo 154
}

(Received February 28, 1990)

\begin{abstract}
Constitution and molecular species of triacylglycerol (TG) from meats (breast and thigh) and giblets (liver, heart and gizzard) of White Leghorn hens were determined to evaluate the lipid quality of spent hen as foodstuff. Main fatty acids comprised in spent hen tissue TG were palmitic $(16: 0)$, stearic $(18: 0)$, oleic $(18: 1)$ and linoleic (18:2) acids. TG from breast, thigh, heart and gizzard resembled in their fatty acid compositions, but TG from liver had higher contents of $18: 0$ and $18: 1$ acids, and lower content of $18: 2$ acid than TG of other tissues tested. Excepting liver, every tissue tested contained similar amounts of $\mathrm{S}_{2} \mathrm{D}, \mathrm{SMD}, \mathrm{SD}_{2}$ and $\mathrm{MD}_{2}$, respectively, and it was supposed that these tissue lipids had comparatively resembled constitution of TG, while, liver alone was significantly differed from the other tissues, on the amount of $\mathrm{SM}_{2}, \mathrm{~S}_{2} \mathrm{D}$, $\mathrm{M}_{2} \mathrm{D}, \mathrm{SD}_{2}$ and $\mathrm{MD}_{2}$. In spent hen tissues, saturated fatty acids were esterified more on position 1 than positions 2 and 3 of TG, and unsaturated fatty acids predominated in position 2. Most abundant TG type was triunsaturated TG (sn-UUU), then followed by sn-SUU, sn-UUS, sn-SUS, sn-USU, sn-SSU and sn-USS in decreasing order, and sn-SSS was the least constituent in every tissue lipid. Also, assuming a 1-random, 2-random, 3-random arrangement, the major TG species in spent hen tissue lipids were considered as sn-OOO, sn-OOP, sn-POO, sn-OLO, sn-POP, sn-PLO and sn-OLP etc.

(Abbreviation used in this are as follows: $S=$ saturated, $U=$ unsaturated, $M=$ monoenoic, $\mathrm{D}=$ dienoic, $\mathrm{P}=$ palmitic, $\mathrm{O}=$ oleic, $\mathrm{L}=$ linoleic acids, and $\mathrm{sn}-=$ stereospecifically numbered.)
\end{abstract}

Jpn. J. Zootech. Sci., (10) : 937-944, 1990

Key words : spent layer, giblet lipid, triacylglycerol, chromatography, stereospecific study

The egg industry is faced with large numbers of spent laying hens which are of ten difficult to market at a reasonable return. In U.S.A., whole spent layer carcasses are now utilized as an important source of usable poultry meat in the manufacture of the comminuted items and restructured products by mechanical deboning and flake processing ${ }^{10,24)}$. As poultry lipids are rich in highly unsaturated fats, poultry meat tends to become rancid faster than beef or lamb $b^{13)}$. Studies by a number of reseachers have revealed that the neutral lipid fraction of various kinds of meat including poultry oxidized slowly, compared with the phospholipid $^{7,15)}$. But, neutral lipids or TG constitute a relatively large portion of total lipids, and play an important role in the physical and rheological properties of lipids.

There have been many reports on fatty acid composition of broiler lipids ${ }^{1,11,22,23)}$, but a few 
published data are available on the lipids from spent layers ${ }^{9,12)}$. Although TG constitutes a large portion of neutral lipid, TG of spent layers have not been studied by this time. The purpose of this study is to determine the constitution and molecular species of TG in various tissue lipids, and to elucidate the lipid quality of spent laying hen from the standpoint of the effective use of poultry byproducts as foodstuff.

\section{Materials and Methods}

Birds and tissue samples

Spent laying hens used in this study were commercial strain layers of White Leghorn. Birds were kept in individual cage, and fed commercial formula feed. Five birds, 528 days of age, were sacrificed after fasting overnight. Breast, thigh, liver, heart and gizzard were removed from each carcass. Samples of each of five tissues were trimmed of all external fat and connective tissues, and kept at $-15^{\circ} \mathrm{C}$ until analysis was carried out.

Extraction of lipid and preparation of triacylglycerol

Tissue samples were minced by a home meat chopper and used for lipid analysis. The total lipid was extracted from each sample according to the method of Folch et al. ${ }^{8}$, and was separated into neutral and phospholipid fractions by the procedure of MOERCK and BALL ${ }^{14)}$. Triacylglycerol (TG) was isolated from the neutral lipid fraction of each tissue by silicic acid column chromatography ${ }^{14)}$.

Argentation thin-layer chromatography

TG was fractionated by argentation thinlayer chromatography $\left(\mathrm{AgNO}_{3}-\mathrm{TLC}\right)$. The plate coated with Silica Gel G containing $\mathrm{AgNO}_{3}$ was prepared by the method of WoOD and SNYDER ${ }^{25)}$, and separation of TG was performed by the method of CHRIsTIE and Moore ${ }^{4)}$. The amount of TG fraction was calculated by reference to the methyl heptadecanoate added as internal standard. The TG types present in the fraction were estimated from the results of fatty acid composition determined on each fraction, as described previously ${ }^{19)}$.

Stereospecific analysis

Stereospecific analysis of TG was carried out essentially following the scheme proposed by BROCKERHOFF ${ }^{2)}$ and modified by CHRISTIE and $\mathrm{MOORE}^{3)}$, as described previously ${ }^{17}$.

Gas-liquid chromatography

The fatty acid composition of lipid was determined by the procedure described previously ${ }^{17}$, using Shimadzu GC-6 A PF Gas Chromatograph and Shimadzu Chromatopac C-R 2 A.

\section{Results and Discussion}

Fatty acid composition of TG of spent laying hen lipid

Fatty acid compositions of TG from meats (breast and thigh) and giblets (liver, heart and gizzard) of spent laying hens are shown in Table 1.

The major fatty acids present in tissue TG were palmitic $(16: 0)$, stearic $(18: 0)$, oleic $(18: 1)$ and linoleic $(18: 2)$ acids. In addition to these acids, small amounts of myristic $(14: 0)$, palmitoleic $(16: 1)$ and eicosenoic $(20: 1)$ acids were found in hen tissues. Although the fatty acid compositions were mutually differed among tissues in details, fairly similar fatty acid patterns were observed in every tissue excepting liver TG which contained more $18: 0$ and $18: 1$, and less $18: 2$ than the other tissues tested.

The quality and composition of poultry lipids are influenced by several factors including age, sex, strain of bird, anatomical location and diet, and these factors have more effects on neutral lipid than polar lipid fraction ${ }^{13,15)}$. In spite of the difference in experimental conditions, breast, thigh and liver TG in the present study had similar fatty acid compositions to those reported by PIKUL et $a l_{.}{ }^{20)}$ on corresponding tissue lipids of 4 months aged chicken. However, our results on heart TG showed less $16: 0$ and more $18: 2$ than the results by 
Table 1. Fatty acid composition of triacylglycerol from spent laying hens

\begin{tabular}{|c|c|c|c|c|c|}
\hline Fatty acid* & Breast & Thigh & Liver & Heart & Gizzard \\
\hline $14: 0$ & 1.2 & 1.2 & 0.6 & 1.4 & 1.3 \\
\hline $16: 0$ & 25.2 & 23.0 & 25.4 & 22.3 & 24.4 \\
\hline $16: 1$ & 4.0 & 5.2 & 4.0 & 4.8 & 4.4 \\
\hline $17: 0$ & 0.4 & 0.6 & 0.4 & 0.4 & 0.4 \\
\hline $17: 1$ & 0.2 & 0.2 & 0.2 & 0.2 & 0.2 \\
\hline $18: 0$ & 6.9 & 5.9 & 8.4 & 5.4 & 5.5 \\
\hline $18: 1$ & 40.3 & 41.3 & 49.4 & 40.9 & 42.2 \\
\hline $18: 2$ & 19.7 & 21.0 & 10.8 & 22.1 & 20.2 \\
\hline $18: 3$ & 0.7 & 0.7 & 0.3 & 0.9 & 0.7 \\
\hline $20: 1$ & 0.8 & 0.7 & 0.4 & 1.1 & 0.7 \\
\hline $20: 2$ & 0.1 & $\operatorname{tr}^{* *}$ & & 0.1 & $\operatorname{tr}$ \\
\hline $20: 3$ & 0.2 & 0.1 & $\operatorname{tr}$ & 0.1 & tr \\
\hline $20: 4$ & 0.3 & 0.1 & 0.1 & 0.3 & 0.1 \\
\hline Sat. acid & 33.7 & 30.7 & 34.8 & 29.5 & 31.6 \\
\hline Monoene & 45.3 & 47.4 & 54.0 & 47.0 & 47.5 \\
\hline Diene & 19.8 & 21.0 & 10.8 & 22.2 & 20.1 \\
\hline Polyene & 1.2 & 0.9 & 0.4 & 1.3 & 0.8 \\
\hline
\end{tabular}

* Number of carbon atoms : number of double bonds.

** $\mathrm{tr}=$ trace (below $0.1 \%$ ). Sat. acid; saturated fatty acids.

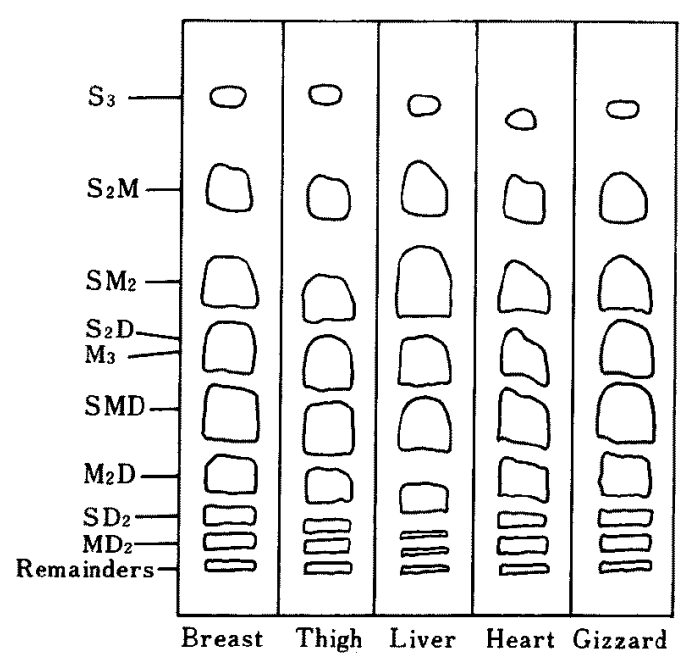

Fig. 1. Argentation thin-layer chromatograms of triacylglycerols of tissue lipids from spent laying hens. Plates: Silica Gel $G$ impregnated with $10 \% \mathrm{AgNO}_{3}$. Developing solvent system : hexane-ethyl ether-benzenemethanol $(70 / 10 / 20 / 1$ by volume). S: Saturated, $M$ : Monoenoic and $\mathrm{D}:$ Dienoic fatty acid.

\section{PIKUL et al. ${ }^{21)}$.}

Fractionation of TG class by $\mathrm{AgNO}_{3}-\mathrm{TLC}$ Intact TG of every tissue lipid was fractionated by means of $\mathrm{AgNO}_{3}-\mathrm{TLC}$ into different classes depending on unsaturation and polarity of TG. The chromatograms of each TG are shown in Fig. 1.

Nine or more bands of TG classes were detected on the plates. The results of quantitative analysis of each tissue TG are shown in Table 2. Remainders contained many polyunsaturated or highly polarized TG components that were retained on near the origin. Those TG classes were not determined qualitatively.

Trisaturated TG $\left(\mathrm{S}_{3}\right)$ was a small TG component in every tissue lipid. Breast, thigh, heart and gizzard lipids contained similar amounts of TG classes of $\mathrm{S}_{2} \mathrm{D}, \mathrm{SMD}, \mathrm{SD}_{2}$ and $\mathrm{MD}_{2}$, respectively. Accordingly, it was considered that those four tissue lipids had comparatively resembled TG constitution. However, liver TG had the most amount of $\mathrm{SM}_{2}$ and the least of $S_{2} D, M_{2} D, S D_{2}$ and $M_{2}$ among the tissues tested. Therefore, liver alone differed from the other tissues on the TG composition.

HUSBANDs $^{12)}$ studied the lipids of liver and adipose tissue from layer of White Leghorn strain, and reported that $\mathrm{SM}_{2}$ was contained about $40 \%$ in liver $\mathrm{TG}$ and that the amounts of 
$\mathrm{SM}_{2}$ and SMD were both estimated as about 20 $\%$ in adipose tissue TG of hens. Consequently, he recognized the different feature between liver and adipose tissue in reference to the TG compositions.

The contents of $\mathrm{SM}_{2}$ in liver, also of $\mathrm{SM}_{2}$ and SMD in adipose tissue from layers reported by HUSBANDS $^{12)}$ agreed closely with our results obtained on the spent hen lipids.

Fatty acid distribution in spent hen tissue lipids
Positional distribution of fatty acids in TG molecule of spent layer tissue lipids was investigated by stereospecific analysis. The results obtained are shown in Table 3.

Each fatty acid which is comprised in TG possesses specific characteristics in relation to positional and proportional distribution on stereospecifically numbered positions of TG. In the lipids from spent layers, $14: 0$ and $16: 1$ were esterified more on position 3 than on positions 1 and 2 of TG. Although saturated

Table 2. Component triacylglycerol species of tissue lipids from spent laying hens

\begin{tabular}{crrrrr}
\hline TG type* & Breast & Thigh & Liver & Heart & Gizzard \\
\hline $\mathrm{S}_{3}$ & 3.0 & 2.8 & 2.6 & 2.6 & 2.5 \\
$\mathrm{~S}_{2} \mathrm{M}$ & 14.7 & 12.5 & 15.5 & 12.0 & 14.6 \\
$\mathrm{SM}_{2}$ & 20.6 & 19.0 & 38.3 & 17.4 & 21.3 \\
$\mathrm{~S}_{2} \mathrm{D}$ & 8.4 & 8.3 & 4.4 & 1.9 & 8.1 \\
$\mathrm{M}_{3}$ & 9.1 & 11.0 & 10.9 & 21.0 & 10.2 \\
$\mathrm{SMD}_{\mathrm{M}}$ & 20.7 & 21.5 & 17.1 & 13.0 & 20.8 \\
$\mathrm{M}_{2} \mathrm{DD}$ & 9.7 & 12.0 & 6.4 & 5.1 & 11.7 \\
$\mathrm{SD}_{2} \mathrm{~T}$ & 4.5 & 5.0 & 1.7 & 0.8 & 4.3 \\
$\mathrm{MD}$ & 0.7 & 0.8 & 0.5 & 3.2 & 0.7 \\
Remainders & 2.9 & 2.7 & 0.3 & 5.7 & 2.4 \\
\hline
\end{tabular}

*S: Saturated, M : Monoenoic, D : Dienoic and $\mathrm{T}:$ Trienoic fatty acid.

Table 3. Positional distributions of fatty acids in triacylglycerols of tissue lipids from spent laying hens

\begin{tabular}{|c|c|c|c|c|c|c|c|c|c|c|}
\hline \multirow{2}{*}{ Tissue } & \multirow{2}{*}{$\begin{array}{l}\text { Position } \\
\text { in TG }\end{array}$} & \multicolumn{7}{|c|}{ Fatty acid } & \multirow[b]{2}{*}{$\begin{array}{l}\text { Sat. } \\
\text { acid }\end{array}$} & \multirow[b]{2}{*}{$\begin{array}{l}\text { Unsat. } \\
\text { acid }\end{array}$} \\
\hline & & $14: 0$ & $16: 0$ & $16: 1$ & $18: 0$ & $18: 1$ & $18: 2$ & Others* & & \\
\hline \multirow{3}{*}{ Breast } & $1^{* *}$ & 0.6 & 30.1 & 3.0 & 13.1 & 41.5 & 9.2 & 2.5 & 44.2 & 55.8 \\
\hline & $2^{* *}$ & 1.0 & 17.1 & 2.5 & 2.9 & 42.3 & 32.2 & 2.0 & 21.5 & 78.5 \\
\hline & $3^{* *}$ & 2.0 & 28.4 & 6.5 & 4.7 & 37.1 & 17.7 & 3.6 & 35.4 & 64.6 \\
\hline \multirow{3}{*}{ Thigh } & 1 & 1.1 & 27.2 & 5.5 & 8.2 & 39.7 & 15.6 & 2.7 & 37.1 & 62.9 \\
\hline & 2 & 1.0 & 14.9 & 3.0 & 3.5 & 42.0 & 33.0 & 2.6 & 20.6 & 79.4 \\
\hline & 3 & 1.5 & 26.9 & 7.1 & 6.0 & 42.2 & 14.4 & 1.9 & 34.4 & 65.6 \\
\hline \multirow{3}{*}{ Liver } & 1 & 0.4 & 38.3 & 3.5 & 10.9 & 42.4 & 3.4 & 1.1 & 50.0 & 50.0 \\
\hline & 2 & 0.5 & 6.4 & 2.7 & 4.5 & 60.3 & 24.3 & 1.3 & 11.6 & 88.4 \\
\hline & 3 & 0.9 & 31.5 & 5.8 & 9.8 & 45.5 & 4.7 & 1.8 & 42.8 & 57.2 \\
\hline \multirow{3}{*}{ Heart } & 1. & 0.7 & 25.7 & 5.2 & 12.3 & 45.9 & 8.2 & 2.0 & 39.1 & 60.9 \\
\hline & 2 & 1.1 & 13.2 & 2.9 & 2.5 & 43.7 & 34.3 & 2.3 & 17.2 & 82.8 \\
\hline & 3 & 2.4 & 28.0 & 6.3 & 1.4 & 33.1 & 23.8 & 5.0 & 32.2 & 67.8 \\
\hline \multirow{3}{*}{ Gizzard } & 1 & 1.2 & 29.9 & 5.3 & 7.7 & 40.2 & 13.6 & 2.1 & 39.3 & 60.7 \\
\hline & 2 & 0.7 & 13.7 & 2.4 & 2.3 & 44.7 & 34.6 & 1.6 & 17.0 & 83.0 \\
\hline & 3 & 2.0 & 29.6 & 5.5 & 6.5 & 41.7 & 12,1 & 2.6 & 38.5 & 61.5 \\
\hline
\end{tabular}

* Contained $17: 0,17: 1,18: 3,20: 1,20: 2,20: 3$ and $20: 4$.

** Stereospecific number in triacylglycerol. 
fatty acids, such as $16: 0$ and $18: 0$ were found less in position 2 than positions 1 and $3,16: 0$ was rather evenly distributed in both positions 1 and 3. Position 1 of hen tissue TG was preferentially occupied by $18: 0$, except the liver in which 18:0 was distributed evenly in positions 1 and 3 .

TG from layer tissues other than liver had comparatively even distribution of $18: 1$ in each position of TG. In every tissue, 18:2 was predominantly distributed in position 2 , and proportional distribution of $18: 2$ in position 2 of liver TG was estimated as up to $75 \%$.

In all, saturated fatty acids were found more in positions 1 and 3 than in position 2, while, unsaturated fatty acids present abundantly in position 2 of TG. Especially, position 2 of TG from liver was largely (about $88 \%$ ) occupied by unsaturated fatty acids. In addition, proportional distribution of unsaturated acids in position 2 of TG was higher in giblets than in the breast and thigh.

This characteristic distribution patterns of fatty acids in poultry tissue TG were similarly recognized by CHRISTIE and MOORE ${ }^{5,6)}$ on the lipids of chicken liver, heart and adipose tissue, and also by OHTAKE ${ }^{18)}$ on the lipid of chicken bone marrow.

Molecular species of TG of spent laying hen

The amounts of TG types and individual molecular species of TG were determined on spent layer tissues. The results obtained are shown in Table 4.

The most abundant TG type in every tissue was sn-UUU estimating as $1 / 4 \sim 1 / 3$ part of total TG, then sn-SUU, sn-UUS, sn-SUS, snUSU, sn-SSU and sn-USS were followed in decreasing order on their contents in tissue TG. Trisaturated TG (sn-SSS) was the least constituent in every tissue TG, and the determined values of sn-SSS in each tissue are nearly equal to the results of $S_{3}$ contents obtained by $\mathrm{AgNO}_{3}$-TLC procedure on corresponding tissue lipids, respectively.

The amounts of $U_{3}$ in this study on spent layer was more and $\mathrm{S}_{2} \mathrm{U}$ was less than the results obtained by OHTAKE and WATANABE ${ }^{16}$ from the research on broiler meats. This suggests that spent layer lipids are more unsaturated than broiler lipids.

Triolein (sn-OOO) was the most abundant TG species in every tissue lipid, and other main TG species such as sn-POP, sn-POO, sn-PLO, sn-OOP, sn-OLP, sn-OOL and sn-OLO were found in spent laying hen tissue lipids. Not so large differences were found among the spent hen tissues tested, except liver, as to the amounts of each TG species. Lipid of liver had significantly higher amounts of certain TG species, e.g. sn-POP, sn-POO, sn-OOP and $\mathrm{sn}-\mathrm{OOO}$ than the lipid of other tissues.

DAwson and GARTNER ${ }^{\text {7) }}$ described in their review article that the nature, proportion and degree of unsaturation of fatty acids present in a lipid system or food would indicate the approximate susceptibility of that product to oxidative deterioration. A general survey of our study on the TG constitution of hen tissue lipids proved that spent layer lipids were rich in many TG species which comprised both $18: 1$ and $18: 2$. Present study showed that the total amount of $\mathrm{SU}_{2}$ and $\mathrm{U}_{3}$ formed about $3 / 4$ part of total TG in hen tissues. Consequently, lipids from spent layer tissues have lower melting point and are more susceptible to oxidative rancidity as compared with the lipids from meats of domestic animals. Therefore, reasonable consideration to oxidation should be paid during processing and storage of spent layer tissues when they are used as ingredients to food.

\section{Acknowledgements}

Birds used in this study were obtained from Fujisawa Farm attached to College of Agriculture and Veterinary Medicine, Nihon University. The authors express our appreciation to the members of the Farm. We also wish to thank Professor K. YAMAuchI of Nihon University for critical reading of the manuscript. 
Table 4. Triacylglycerol composition and main component triacylglycerols of tissue lipids from spent laying hens

\begin{tabular}{|c|c|c|c|c|c|}
\hline TG type* & Breast & Thigh & Liver & Heart & Gizzard \\
\hline sn-SSS & 3.4 & 2.6 & 2.5 & 2.2 & 2.6 \\
\hline sn-PPP & 1.5 & 1.1 & 0.8 & 0.9 & 1.2 \\
\hline sn-SSU & 6.1 & 5.0 & 3.3 & 4.6 & 4.1 \\
\hline sn-PPO & 1.9 & 1.7 & 1.1 & 1.1 & 1.7 \\
\hline sn-SUS & 12.3 & 10.1 & 18.9 & 10.4 & 12.6 \\
\hline sn-POP & 3.6 & 3.1 & 7.3 & 3.1 & 4.0 \\
\hline sn-POSt & 0.6 & 0.7 & 2.3 & 0.2 & 0.9 \\
\hline sn-PLP & 2.8 & 2.4 & 2.9 & 2.5 & 3.1 \\
\hline sn-StOP & 1.6 & 0.9 & 2.1 & 1.5 & 1.0 \\
\hline sn-USS & 4.2 & 4.5 & 2.5 & 3.4 & 4.0 \\
\hline sn-OPP & 2.0 & 1.6 & 0.9 & 1.7 & 1.6 \\
\hline sn-SUU & 22.4 & 19.3 & 25.3 & 22.0 & 20.1 \\
\hline$s n-P O O$ & 4.7 & 4.8 & 10,5 & 3.7 & 5.6 \\
\hline sn-StOO & 2.1 & 1.5 & 3.0 & 1.8 & 1.4 \\
\hline sn-POL & 2,3 & 1.6 & 1.1 & 2.7 & 1.6 \\
\hline sn-PLO & 3.6 & 3.8 & 4.2 & 2.9 & 4.3 \\
\hline sn-StLo & 1.6 & 1.1 & 1,2 & 1.4 & 1.1 \\
\hline sn-PLL & 1.7 & 1.3 & 0.4 & 2.1 & 1.3 \\
\hline $\mathrm{sn}^{-} \mathrm{USU}$ & 7.8 & 8.5 & 3.3 & 7.1 & 6.3 \\
\hline sn-OPO & 2.6 & 2.5 & 1.2 & 2.0 & 2.3 \\
\hline sn-UUS & 15.5 & 17.2 & 18.9 & 16.2 & 19.4 \\
\hline sn-OOP & 5.0 & 4.5 & 8.1 & 5.6 & 5.3 \\
\hline sn-OOSt & 0.8 & 1.0 & 2.5 & 0.3 & 1.2 \\
\hline sn-OLP & 3.8 & 3.5 & 3.2 & 4.4 & 4.1 \\
\hline sn-UUU & 28.3 & 32.8 & 25.3 & 34.2 & 31.0 \\
\hline $\mathrm{sn}-\mathrm{OOPt}$ & 1.1 & 1.2 & 1.5 & 1.3 & 1.0 \\
\hline $\mathrm{sn}-\mathrm{OOO}$ & 6.5 & 7.0 & 11.6 & 6.6 & 7.5 \\
\hline sn-OOL & 3.1 & 2.4 & 1.2 & 4.8 & 2.2 \\
\hline sn-OLO & 5.0 & 5.5 & 4.7 & 5.2 & 5.8 \\
\hline sn-LOO & 1.4 & 2.8 & 0.9 & 1.2 & 2.5 \\
\hline$s n-O L L$ & 2.4 & 1.9 & 0.5 & 3.7 & 1.7 \\
\hline sn-LLO & 1.1 & 2.2 & 0.4 & 0.9 & 2.0 \\
\hline
\end{tabular}

* Calculated triacylglycerol type by means of 1-randam, 2-randam, 3-randam distribution.

sn-: stereospecifically numbered.

$\mathrm{S}$ : Saturated, U : Unsaturated, P : Palmitic, $\mathrm{Pt}:$ Palmitoleic, St: Stearic, O : Oleic and L : Linoleic acid.

\section{References}

1) Becker, W.A. and L.A. Mirosh, Abdominal fat in broiler breeders. Poultry Sci., $63:$ 819-821. 1984.

2) Brockerнoff, H., Stereospecific analysis of triglycerides: An analysis of human depot fat. Arch. Biochem. Biophys., 110 ; 586-592. 1965.

3) Christie, W.W. and J.H. MOORE, A semimicro method of the stereospcific analysis of triglycerides. Biochim. Biophys. Acta, 176 : 445-452. 1969.

4) Christie, W.W. and J.H. Moore, A comparison of the structures of triglycerides from various pig tissues. Biochim. Biophys. Acta, $210: 46-56.1970$.

5) Christie, W.W. and J.H. MOORE, The structures of adipose tissue and heart muscle triglycerides in the domestic chicken (Gallus gallus). J. Sci. Food Agric., $23: 73-77.1972$.

6) Christig, W.W. and J.H. MOORE, The lipid components of the plasma, liver and ovarian follicles in the domestic chicken (Gallus gallus), Comp. Biochem. Physiol., 41 B : 287-295. 1972.

7) Dawson, L.E. and R. GARTnER, Lipid oxidation in mechanically deboned poulty. Food Technol., $37: 112-$ 116. 1983.

8) Folch, J., M. Lees and G.H. Sloane-Stanley, A simple method for the isolation and purification of total lipids from animal tissues. J. Biol. Chem., 226 : 497-509. 1957.

9) Hirata, A., F.C. Wang, T. Kimura and Y. Ohtake, Fatty acid composition of lipids of meats and various 


\section{Triacylglycerol of Spent Layer Tissue Lipids}

internal organs from culled laying hen. Nippon Shokuhin Kogyo Gakkaishi. 35 : 204-209. 1988.

10) Hollender, R., J.H. MACNEIL and M.G. MAST, Effect of fragmentation method and formulation on the quality of patties made from restructured spent layer meat. J. Food Sci., 52 : 290-293. 1987.

11) Hulan, H.W., F.G. Proudfoor and D.M. NASH, The effects of different dietary fat sources on general performance and carcass fatty acid composition of broiler chickens. Poultry Sci., 63: 324-332. 1984.

12) Husbands, D.B., The composition of triglcerides from liver, egg yolk and adipose tissue of the laying hen. Biochem. J., 120 : 365-371. 1970.

13) LEE, W.T. and L.E. DAwson, Chicken lipid changes during cooking in fresh and reused cooking oil. J. Food Sci., $38:$ 1232-1237. 1973.

14) MozrCK, K. and H.R. BALL JR., Lipids and fatty acids of chicken bone marrow. J. Food Sci., $38: 978$ 980. 1973.

15) MOERCK, K. and H.R. BALL JR., Lipid autoxidation in mechanically deboned chicken meat. J. Food Sci., 39: 876-879. 1974

16) ОнтАKE, $Y$. and M. WATANABE, Chemical studies on the lipids of chicken tissues II. Fatty acid and triglyceride composition of broiler lipids. Jpn. J. Zootech. Sci., 42 : 519-525. 1971.

17) OHTAKE, Y., Fatty acid distribution of bovine and porcine bone marrow lipids. Jpn. J. Zootech. Sci., 53 : 797-803. 1982.
18) OhtAKe, Y., Fatty acid distributions in chicken bone marrow lipids.. J. Jap. Soc. Nutr. Food Sci, 36 : 119121. 1983.

19). OHTAKE, Y., Triacylglycerol compositions and structural features of soft fat pork lipids. Jpn. J. Zootech. Sci., $54:$ 179-186. 1983.

20) Pikul, J., D.E. Leszcz ynski and F.A. Kummerow, Influence of fat content and composition on malonaldehyde concentration in chicken meat and skin. Poultry Sci., 64: 311-317. 1985.

21) Pikul, J., D.E. Leszczynski and F.A. Kummerow, Total lipids, fat composition, and malonaldehyde concentration in chicken liver, heart, adipose tissue, and plasma. Poultry Sci., 64: 469-475. 1985.

22) Sahasrabudhe, M.R., N.F. Delorme, D.F. Wood and C.J. RANDALL, Neutral and polar lipids in chicken parts and their fatty acid composition. Poultry Sci., $64: 910-916.1985$.

23) Sarra, C., M. Boccignone and L. Damasio, The effect of age, sex, and anatomical location on the fatty acid composition of pheasant meat. Poultry Sci., 64 : 1090-1097. 1985.

24) Seideman, S.C., P.R. DuRland, N.M. Quenzer and C.W. CARLSON, Utilization of spent fowl muscle in the manufacture of restructured steaks. Poultry Sci., 61 : 1087-1093. 1982.

25) Wood, R. and F. SNYDeR, Modified silver ion thinlayer chromatogaphy. J. Am. Oil Chem. Soc., $43: 53-$ 54. 1966 
Hirata, Wang, Kimura and Ohtake

\title{
廃鶏の肉および内臟脂質のトリアシルグリセロールの 構造ならびに分子種
}

\author{
平田明弘・王＼cjkstart逢周・木村貞司・大武由之 \\ 日本大学農獣医学部，東京都世田谷区 154
}

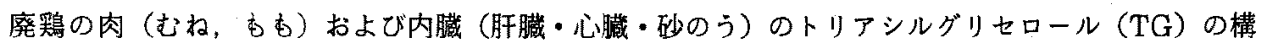
造ならびに分子種を研究した．廃鶏 $\mathrm{TG}$ の主要な脂肪酸はパルミチン酸，ステアリン酸，オレイン酸 およびリノール酸であった。むね，むむ，心葴および砂のうの TG の脂肪酸組成はよく似ていたが， 肝缄は他の組織に比べてステアリン酸とオレイン酸が多く，リノール酸が少なかった．肝荿を除く各組 織は $\mathrm{S}_{2} \mathrm{D}, \mathrm{SMD}, \mathrm{SD}_{2}$ おょび $\mathrm{MD}_{2}$ の含量がそれぞれ近似していて, 比較的似た TG 構造であった。 しかし，肝臓の $\mathrm{SM}_{2}, \mathrm{~S}_{2} \mathrm{D}, \mathrm{M}_{2} \mathrm{D}, \mathrm{SD}_{2}$ および $\mathrm{MD}_{2}$ の含量は他の組織と明らかに異なっていた，廃鶏 において飽和脂肪酸は TGの 2 および 3 の位置より1の位置に多く，不飽和脂肪酸は 2 の位固に多く 存在していた。廃鶏の TG タイプでは sn-UUU が最も多く, 次いで sn-SUU, sn-UUS, sn-SUS, sn-USU, sn-SSU および sn-USS の順であり，sn-SSS はいずれの組織においてあ最す少ない成分 であった。 1-ランダム、2-ランタム、3-ランダム分布理論に基いて計算した廃䉆 TG の主要な分子種 は sn-OOO, sn-OOP, sn-POO, sn-OLO, sn-POP, sn-PLO おょび sn-OLP であった.（S=飽和 脂肪酸， $\mathrm{U}=$ 不飽和脂肪酸， $\mathrm{M}=$ モノエン酸， $\mathrm{D}=$ ジェン酸， $\mathrm{P}=$ パルミチン酸， $\mathrm{O}$ =オレイン酸， $\mathrm{L}$ =リノール酸, $\mathrm{sn}^{-}=$立体特異的番号をあらわす.)
\end{abstract}

日畜会報, $61(10): 937-944,1990$ 